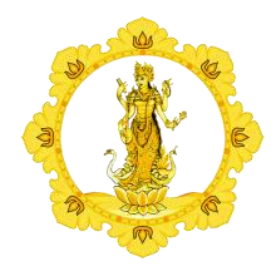

KALANGWAN

JURNAL PENDIDIKAN AGAMA, BAHASA DAN SASTRA

Vol. 11 No. 1 Maret 2021

\begin{tabular}{|l|l|l|}
\hline p-ISSN : 1979-634X & e-ISSN : 2686-0252 & http://ejournal.ihdn.ac.id/index.php/Kalangwan
\end{tabular}

\title{
URGENSI PENDIDIKAN KARAKTER (Kajian Filsafat Pendidikan)
}

\author{
Oleh : \\ I Made Putra Aryana \\ Universitas Hindu Negeri I Gusti Bagus Sugriwa Denpasar \\ E-mail: madeputra84@gmail.com
}

Diterima 05 Januari 2021, direvisi 08 Januari 2021, diterbitkan 31 Maret 2021

\begin{abstract}
This article aims to examine the importance of character education to create Indonesian people who have knowledge, have noble morals, have personality and character. The writing of this article uses the librarian method and in-depth study of the literature. The issue of the character of students and the character of the nation is currently the most important issue for the world of education in the country. Education includes two main interests, namely the development of individual potential and the inheritance of cultural values. There are three foundations that make up the philosophy of education, namely: the ontological, epistemological and axiological foundation. A person who is studying education is required to think about essential problems regarding education. Various problems of the nation today can only be fixed by individuals of the younger generation with character: smart, quality, ethical, disciplined, honest, hard work and moral. It is hoped that the development of Indonesia's young generation can become the identity of the nation's children in the era of globalization and acculturation of world culture, and can encourage independence in an effort to increase the competitiveness of Indonesia's young generation. The back and forth of the nation's future is very much determined by the quality of human resources who are intelligent, have character, have good character, in accordance with the philosophy and goals of national education.
\end{abstract}

\section{Keywords: Character Education, Educational Philosophy}

\section{Pendahuluan}

Persoalan karakter anak didik dan karakter bangsa ini menjadi isu terpenting bagi dunia pendidikan di tanah air. Anak didik yang mempunyai karakter yang tangguh tidak diragukan lagi, bahwa hal ini merupakan 
solusi bagi beragam persoalan social yang sedang dan akan dihadapi bangsa ini. Beragam persoalan social, sejak dari isu kenakalan remaja, tawuran, perilaku korupsi, narkoba dan obat terlarang, konflik social, dan lain-lainnya, agaknya berawal dari proses penddidikan nasional yang belum selaras dengan tujuan filosofis pendidikan nasional.

Sebagai upaya sadar untuk menciptakan sumber daya manusia (human resources) yang berkarakter seperti yang diharapkan, institusi pendidikan memiliki peranan terdepan. Institusi pendidikan di Indonesia, sejak Sekolah Dasar (SD), hingga perguruan tinggi memiliki peranan strategis dalam menciptakan anak didik dan generasi muda berkarakter yang dapat bertindak sebagai 'pemain'. Sebagai "pemain" generasi muda Indonesia hendaklah memilki berbagai bekal, tidak hanya memiliki ilmu pengetahuan pragmatis tetapi juga perlu memiliki integritas, karakter dan moralitas. Lebih lanjut, tanpa mengedepankan karakter suatu bangsa akan sulit menjadi maju seperti diharapkan, karena Negara menjadi maju selalu berkorelasi dengan kekuatan basis karakter atau ahklak yang dimiliki generasi mudanya. Fakta social memperlihatkan bahwa sebagian generasi muda bangsa ini mungkin sudah menjadi "korban" era ini, yang cenderung mengedepankan pragmatisme, hedonism, meterialisme dan budaya cepat saji (Abdulah Idi, 2013: 235).

\section{Pembahasan}

Tujuan filosofis pendidikan nasional secara garis besar, sebagai upaya membentuk anak didik yang memiliki kompetensi sainsteknologi maupun sains-agama, atau agar mereka beriptek dan berimtak. Tujuan pendidikan nasional adalah menciptakan manusia Indonesia yeng memiliki pengetahuan, berahklak mulia, berkepribadian dan berkarakter. Dalam Undang-Undang No 20/2003 tentang Sistem Pendidikan Nasional, dinyatakan:

Pendidikan adalah usaha sadar dan terencana untuk mewujudkan suasana belajar dan proses pembelajaran agar peserta didik secara aktif mengembangkan potensi dirinya untuk memiliki kekuatan spiritual keagamaan, pengendalian diri, kepribadian, kecerdaasan, ahklak mulia, serta keterampilan diperlukan dirinya, masyarakat, bangsa dan Negara (UU Republik Indonesia No 20 Tahun 2003 tentang Sistem Pendidikan Nasional).

Produk pendidikan nasional yang diharapkan, tidak hanya cerdas dan pintar tetapi juga berahklak, bermoral dan berkarakter, sehingga mereka bisa hidup dalam zamannya. Abdulah Idi (2013: 195) mengungkapkan bahwa pendiidkan merupakan suatu usaha sadar yang diberikan atau disampaikan dari orang dewasa kepada anak yang belum dewasa menuju perkembangan kearah kedewasaan pribadi yang matang dan mandiri, baik jasmani maupun rohani.

\section{Kepribadian Manusia dan Filsafat Pendidikan}

Peningkatan sumber daya manusia tentunya berbeda dari zaman ke zaman. Sifatnya, bentuknya dan arahannya tergantung dari kondisi lingkungan dan kebutuhan masyarakat masing-masing. Dalam komunitas nelayan, peningkatan kualitas sumber daya manusia diarahkan pada upaya membentuk seseorang menjadi nelayan yang terampil. Peningkatan sumber daya manusia terlihat dari mereka yang semula awam terhadap masalah yang menyangkut kehiddupan nelayan menjadi nelayan yang professional. Peningkatan kualitas ini setidaknya mampu mengangkat status orang yang semula hanya nelayan gurem, menjadi nelayan professional. Demikian pula halnya pada lingkungan kehidupan masyarakat tani, pedagang dan lainnya.

Pada masyarakat tradisional, peningkatan kualitas sumber daya manusia masih terbatas pada aspek-aspek tertentu, yang erat kaitannya pada tradisi setempat. Peningkatan kualitas tersebut tidak lepas hubungannya dari filsafat hidup dan keperibadian masing-masing. Filsafat 
diartikan sebagai kepribadian jati diri dan pandangan hidup seseorang, masyarakat atau bangsa. kondisi ini dibentuk oleh tradisi kehidupan masyarakat ataupun oleh usaha yang terprogram. Segala pembentukan tersebut tidak bisa lepas dari peran pendidikan (Jalaluddin, 2017: 189).

Pendidikan menurut sudut pandang individu adalah usaha untuk membimbing dan menghibungkan potensi individu, sedangkan menurut sudut pandang masyarakat, pendidikan adalah suatu usaha mewariskan nilai-nilai budaya dari generasi tua kepada generasi muda agar nilai-nilai budaya tersebut tetap terpelihara. Hubungan antara pendidikan, tradisi budaya, dan kepribadian suatu masyarakat adalah ketika tradisi sebagai muatan budaya senantiasa terlestarikan dalam masyarakat, dari generasi ke generasi berikutnya. Pelestarian nilai-nilai budaya tersebut, hanya akan mungkin terlaksana apabila ada pendukungnya, dan menularkan pada generasi berikutnya.

Transfer nilai budaya yang paling efektif adalah melalui proses pendidikan. Dalam masyarakat modern, proses pendidikan didasarkan pada suatu system yang sengaja dirancang sebagai suatu program pendidikan secara formal. Sehingga dalam penyelenggaraannya dibentuk lembaga pendidikan formal.

Pendidikan mencakup dua kepentingan utama, yaitu pengembangan potensi individu dan pewarisan nilai-nilai budaya. Kedua hal ini berkaitan erat dengan pandangan hidup suatu masyarakat atau bangsa itu masing-masing. System pendidikan mengandung karakteristik tentang jati diri atau pandangan hidup masyarakat atau bangsa.

Pandangan hidup yang merupakan jati diri ini berisi nilai-nilai yang dianggap sebagai sesuatu yang secara ideal adalah benar. Nilai kebenaran itu sendiri berbeda antara masyarakat atau bangsa satu dengan yang lainnya. Nilai kebenaran yang idealis ini disebut sebagai filsafat hidup yang dijadikan dasar dalam penyusunan system pendidika. Selain itu, nilai-nilai tersebut juga sekaligus dijadikan tujuan yang akan dicapai dalam pelaksanaan system pendidikan dimaksud.

Bangsa Indonesia memiliki filsafat dan pandangan hidup tersendiri, yaitu Pancasila. Pandangan hidup ini dengan sendirinya menjadi dasar sekaligus tujuan pendidikan nasional disusun atas ddasar filsafat pendidikan Pancasila. Sebab, filsafat pendidikan merupakan ilmu pendidikan yang bersendikan filsafat atau filsafat yang diterapkan dalam usaha pemikiran dari pemeccahan masalah-masalah pendidikan.

Pendidikan bila dikembalikan pada fungsinya sebagai usaha untuk mengembangkan potensi individu dan sekaligus sebagai usaha mewariskan nilainilai budaya, maka pendidikan juga menyangkut pembentukan kepribadian. Pendidikan berkaitan dengan usaha untuk mengubah sikap dan tingkah laku. Sedangkan kepribadian berhubungan dengan tingkah laku.

Kepribadian dapat dilihat dari empat aspek muatannya (Jalaluddin, 2017: 195):

1. Aspek personalia, yaitu kepribadian dilihat dari pola tingkah laku lahir dan batin yag dimiliki seseorang.

2. Aspek individualitas, yaitu karakteristik atau sifat-sifat khas yang dimiliki seseorang, hingga dengan adanya sifat-sifat ini seseorang secara individu berbeda dengan individu lainnya.

3. Aspek mentalitas, yaitu sebagai perbedaan yang berkaitan dengan cara berpikir. Mentalitas sebagai gambaran pola pikir seseorang.

4. Aspek identitas, yaitu kecenderungan seseorang untuk mempertahankan sikap dirinya dari pengaruh luar. Identitas merupakan karakteristik yang menggambarkan jati diri seseorang.

Berdasarkan aspek-aspek tersebut, terlihat hubungan antara pendidikan dan pembentukan kepribadian dan hubugan dengan filsafat pendidikan yang bersumber dari nilai-nilai budaya sebagai pandangan hidup suatu bangsa. 


\section{Landasan Filsafat Pendidikan}

Filsafat membentuk dan memberikan asumsi-asumsi dasar bagi setiap ilmu pengetahuan, tidak terkecuali pendidikan. Saat filsafat membahas ilmu alam, maka diperoleh filsafat ilmu alam. Ketika filsafat mempertanyakan konsep dari hukum, maka terbentuklah filsafat hukum, dan ketika filsafat mengkaji permasalahan pendidikan, maka terciptalah cabang filsafat pendidikan.

Terdapat tiga landasan yang membentuk filsafat pendidikan, yaitu: landasan ontologis, epistemologis dan aksiologis.

\section{Ontologi Filsafat Pendidikan}

Ontologi adalah bagian dari metafisika yang bersifat spekulatif, membahas hakikat "yang ada" secara universal. Ontologi berusaha mencari inti yang dimuat setiap kenyataan yang meliputi segala realitas dalam semua bentuknya. Ontologi mempersoalkan hakikat yang tidak dapat dijangkau oleh panca indera belaka.

Sebenarnya, ontologi adalah bagian dari metafisika, sederhananya metafisika dapat didefinisikan sebagai cabang filsafat atau bagian pengetahuan manusia yang bersangkutan dengan pertanyaan mengenai hakikat "ada" yang terdalam.

Semenjak hadirnya pemikiran empiris (pengetahuan yang harus terbuktikan dan teralami secara nyata) banyak yang menyepelekan metafisika. Padahal, pemikiran empiris muncul dari asumsi-asumsi yang dihasilkan oleh ontologi (metafisika).

Einstein menyadari hal ini melalui ucapan ikoniknya yang berkata "imagination is more important than knowledge". Meskipun pemikiran empiris adalah kuda pacu yang diandalkan hari ini, hal tersebut tidak akan tercipta tanpa spekulasi-spekulasi dari pemikiran ontologis. Landasan ontologis memberikan dasar bagi pendidikan mengenai pemikiran tentang "Yang Ada", misalnya pemikiran tentang Tuhan, manusia, dan alam semesta. Corak pendidikan yang akan dilaksanakan sangat dipengaruhi oleh pandangan tentang "Yang Ada" yang telah ditentukan melalui ontologi.
Contoh praktisnya adalah terciptanya kurikulum pendidikan agama untuk pendidikan agama. Tercipta kurikulum pendidikan vokasi untuk menyelenggarakan pendidikan keterampilan. Mengapa? Karena secara ontologis telah diketahui dari awal bahwa pemikiran filsafat itu tujuan pendidikannya berdasarkan "Yang Ada" untuk agama, atau "Yang Ada" untuk vokasi.

\section{Epistemologi Pendidikan}

Epistemologi berarti mempersoalkan sumber dan usul pengetahuan dengan meneliti, mempelajari dan mencoba mengungkapkan prinsip-prinsip primer kekuatan struktur pikiran yang dianugerahkan kepada manusia. Kajian epistemologi membahas tentang bagaimana proses mendapatkan ilmu pengetahuan, hal-hal apakah yang harus diperhatikan agar mendapatkan pengetahuan yang benar, apa yang disebut kebenaran dan apa kriterianya.

Objek telaahnya sendiri adalah untuk mempertanyakan bagaimana sesuatu itu datang, bagaimana kita mengetahuinya, bagaimana kita membedakannya dengan lain. Intinya, objek telaahnya berkenaan dengan situasi, kondisi, ruang dan waktu mengenai sesuatu hal.

Landasan epistemologis memberikan dasar filsafat bagi teori dan praktik pendidikan dalam hal cara memperoleh pengetahuan. Pendidikan itu sangat erat kaitannya dengan ilmu pengetahuan, maka pandangan mengenai sumber dan jenis pengetahuan akan sangat berpengaruh terhadap kurikulum dan model atau metode pembelajaran (pengajaran).

\section{Aksiologi Filsafat Pendidikan}

Ilmu pengetahuan memang telah memberikan manfaat yang besar. Misalnya, bagaimana teori atom dapat digunakan untuk menciptakan energi yang dapat dimanfaatkan dalam kehidupan sehari-hari. Namun, dibalik itu teori ini pula yang membuat kita mampu untuk menciptakan bom atom yang menjadi malapetaka bagi dunia.

Pertanyaan ke mana arah pengetahuan dan pendidikan itulah yang menjadi objek 
pertanyaan utama aksiologi. Aksiologi merupakan cabang filsafat yang membahas teori-teori nilai dan berusaha menggambarkan apa yang dinamakan dengan kebaikan dan perilaku yang baik. Di dalamnya terdapat etika dan estetika. Etika adalah kajian filsafat yang mempersoalkan perilaku manusia terhadap nilai dan moral. Estetika adalah filsafat yang berkaitan dengan kajian keindahan. Keduanya akan berkaitan, karena sesuatu yang indah cenderung akan terasa lebih beretika, begitu pun sebaliknya. Setidaknya, begitulah sebelum filsafat seni kembali mempertanyakannya.

Dalam ranah pendidikan, landasan aksiologis memberikan dasar-dasar filsafat dalam hal nilai dan moral yang melandasi teori pendidikan dan menjadi acuan dalam praktik pendidikan. Karena, pendidikan tanpa nilai dan moral yang positif, pendidikan justru dapat memberikan hal yang negatif. Pendidikan haruslah diimbangi dengan adalah adanya pemberi, penerima, tujuan, dan cara yang baik, dalam konteks yang positif.

\section{Ruang Lingkup Filsafat Pendidikan}

Secara umum filsafat adalah usaha untuk mendapatkan gambaran keseluruhan dari keseluruhan sikap dan kepercayaan yang telah dijunjung tinggi, lalu mempertanyakan . Meskipun skopnya luas, ketika bertemu pendidikan, maka terdapat beberapa rumusan utama. Berikut adalah beberapa kajian utama filsafat pendidikan menurut Rukiyati \& Purwastui (dalam https://serupa.id/filsafatpendidikan-pengertian-sistematika-tujuanaliran/, diakses: 14/11/2020):

1. Merumuskan secara tegas sifat hakiki pendidikan

2. Merumuskan hakikat manusia sebagai subjek dan objek pendidikan.

3. Merumuskan hubungan antara filsafat, filsafat pendidikan, agama dan kebudayaan.

4. Merumuskan hubungan antara filsafat, filsafat pendidikan dan teori pendidikan.

5. Merumuskan hubungan antara filsafat negara (ideologi), filsafat pendidikan dan politik pendidikan (sistem pendidikan)
6. Merumuskan sistem nilai dan norma atau isi moral pendidikan yang menjadi tujuan pendidikan

\section{Tujuan Filsafat Pendidikan}

Tujuan filsafat pendidikan dapat ditinjau dari tujuan filsafat dan pendidikan itu sendiri. Filsafat diantaranya memiliki tujuan untuk mengkritisi suatu kepercayaan dan sikap yang telah dijunjung tinggi, mendapatkan gambaran keseluruhan, analisis logis dari bahasa serta penjelasan tentang arti kata dan konsep.

Sementara itu teori pendidikan bertujuan menghasilkan pemikiran tentang kebijakan dan prinsip-prinsip pendidikan yang didasari oleh filsafat, merumuskan metode praktik pendidikan atau proses pendidikan yang menerapkan serangkaian kegiatan berupa implementasi kurikulum dan interaksi antara pendidik dengan peserta didik untuk mencapai tujuan pendidikan.

Tujuan pendidikan sendiri tergantung dari kebutuhan. Bisa jadi tujuan pendidikan adalah tujuan pendidikan nasional (mencetak generasi penerus bangsa yang baik), instruksional (khusus terhadap keterampilan tertentu), hingga ke tujuan pendidikan institusional (pendidikan militer, dokter, akademisi, dsb).

Selain itu, menurut Amka (2019 dalam https://serupa.id/filsafat-pendidikanpengertian-sistematika-tujuan-aliran/,

diakses: 14/11/2020) tujuan filsafat pendidikan meliputi:

1. Dengan berfikir filsafat seseorang bisa menjadi manusia, lebih mendidik, dan membangun diri sendiri.

2. Seseorang dapat menjadi orang yang dapat berfikir sendiri.

3. Memberikan dasar-dasar pengetahuan, memberikan pandangan yang sintesis pula sehingga seluruh pengetahuan merupakan satu kesatuan.

4. Hidup seseorang dipimpin oleh pengetahuan yang dimiliki oleh seseorang tersebut, sebab itu mengetahui pengetahuan-pengetahuan terdasar berarti mengetahui dasar-dasar hidup diri sendiri. 
5. Bagi seorang pendidik, filsafat mempunyai kepentingan istimewa karena filsafatlah yang memberikan dasar-dasar dari ilmu-ilmu pengetahuan lainnya yang mengenai manusia, seperti misalnya ilmu mendidik.

\section{Manfaat Filsafat Pendidikan}

Seseorang yang sedang menuntut ilmu pendidikan dituntut untuk memikirkan masalah-masalah hakiki mengenai pendidikan. Pemikiran mengenai masalahmasalah pendidikan baik dalam lingkup luas maupun mengerucut akan lebih terasah melalui filsafat pendidikan. Hal tersebut membuat pelajar atau praktisi pendidikan lebih kritis dalam memandang persoalan pendidikan.

Disamping itu filsafat ini juga akan membuat pelajar untuk merenungkan masalah hakiki pendidikan yang secara otomatis akan memperluas cakrawala berpikir dan menjadi lebih arif dalam memahami persoalan pendidikan. Filsafat pendidikan akan menuntut pelajar untuk berpikir reflektif menggunakan kebebasan intelektual yang bertanggung jawab (sistematis).

Selain itu, menurut Amka (2019: 26 dalam https://serupa.id/filsafat-pendidikanpengertian-sistematika-tujuan-aliran/,

diakses: 14/11/2020) filsafat (pendidikan) memiliki manfaat sebagai berikut:

1. Filsafat menolong mendidik.

2. Filsafat memberikan kebiasaan dan kepandaian untuk melihat dan memecahkan persoalanpersoalan dalam kehidupan sehari-hari.

3. Filsafat memberikan pandangan yang luas.

4. Filsafat merupakan latihan untuk berpikir sendiri.

5. Filsafat memberikan dasar-dasar, baik untuk hidup kita sendiri (terutama dalam etika) maupun untuk ilmu-ilmu pengetahuan lainnya, seperti sosiologi, ilmu jiwa, ilmu mendidik, dan sebagainya.

\section{Urgensi Pendidikan karakter di Indonesia}

Sebagian besar generasi muda seringkali terlibat dalam aktivitas dan perilaku negative, seperti tawuran, obat terlarang, pergaulan bebas, criminal, kebutkebutan, hura-hura, dan heddonisme. Jika kondisi ini terus-menerus terjadi dan menjadi kebiasaan selanjutnya akan menjadi karakter. Sudah tentu, akan berdampak buruk bagi peribadi, keluarga, masyarakat dan bagnsa ini ke depan. Beragam persoalan berbangsa berbangsa saat ini hanya dapat diperbaiki oleh individu generasi muda yang berkarakter: cerdas, berkualitas, beretika, disiplin, jujur, kerja keras dan berahklak (Jalaluddin, 2017: 207).

Kebijakan pemerintah, untuk kembali memprioritaskan kebudayaan dalam proses pembangunan generasi muda merupakan bentuk nasional character building generasi muda Indonesia. Pembangunan generasi muda Indonesia diharapkan dapat menjadi indentitas anak bangsa di tengah era globalisasi dan akulturasi budaya dunia, serta dapat mendorong kemandirian dalam upaya peningkatan kemampuan daya saing generasi muda Indonesia. Dalam kaitannya dengan pembangunan masa depan bangsa, Bung karno kerap kali mengungkapkan slogan national character building. Suksesnya pembangunan suatu bangsa agar menjadi bangsa besar dikatakan Bung Karno, mesti dimulai dengan pembangunan manusianya, yang diistilahkan beliau dengan man behin the gun. Selo Soemardjan menyebut dengan manusia pembangunan, yang diantara cirinya adalah memiliki watak yang bermoral tinggi (Desire Zuraidah dan Jufrina, 1993: 35). Karakter moral dan bangsa ini adalah bagaimana sikap dan tingkah laku dan perbuatan suatu bangsa. Moral suatu bangsa adalah kristalisasi dari aneka aragam moral yang ada, baik yang berasal dari adat-istidat secara turun termurun maupun dari berbagai macam agama yang silih berganti memasuki Indonesia (Jalaluddin, 2017: 208).

Dalam suatu diskusi tentang "Memelihara Keutuhan Pembangunan Karakter Bangsa" (diakses Jalaluddin dalam www.beritaindonesia.co.id), dinyatakan 
berbagai sisi kehidupan manusia selama ini luput dari pembangunan karakter, jiwa, dan raga manusia. Sering kali perhatian generasi muda terfokus pada pembangunan ekonomi dan orientasi fisik-material. Dengan karakter demikian, tidak mengherankan jika di kalangan generasi muda tumbuh subur sifatsifat meterialistik, praktek kuropsi, kulusi dan nepotisme (KKN), dan perilaku kurang terpuji lainnya. Karakter sebagian generasi muda ini sudah mengabaikan pembangaunan kemanusiaan. Karakter sebagai gambaran mentalitas sebagian generasi muda saat ini sejalan dengan pendapat antropolog terkemuka Koentjaraningrat, yakni: pertaama: mentalitas meremehkan mutu, kedua: mentalitas suka menerabas, ketiga: sifat tidak percaya diri sendiri, keempat: sifat tidak berddisiplin, dan kelima: sifat tidak bertanggung jawab. Untuk itu mengahadapi globalisasi, karakter generasi muda harus lebing meningkatkan budi pekerti dan sikap menghargai dalam kehidupan sehari-hari.

Selanjutnya Mulyasa (dalam Jalaluddin 2017: 2010) mengungkapkan bahwa di Indonesia pendidikan karakter bangnsa telah berlangsung lama, jauh sebelum Indonesia merdeka. Ki Hajar Dewantara sebagai Pahlawan Pendidikan Nasional berpandangan tentang pendidikan karakter sebagai asas Taman Siswa 1922, memiliki prinsip:

1. Hak seorang mengatur diri sendiri dengan tujuan tertibnya persatuan dalam kehidupan umum;

2. Pengajaran berarti mendidik anak agar merdeka batinnya, pikirannya, dan tenaganya;

3. Pendidikan harus selaras dengan kehidupan;

4. Kultur sendiri yang selaras dengan kodrat harus dapat memberikan kedamaian hidup;

5. Harus bekerja menurut kekuatan sendiri;

6. Perlu hidup dengan berdiri sendiri; dan,

7. Dengan tidak terikat, lahir batin dipersiapkan untuk memberikan pelayanan kepada peserta didik.

Karakter merupakan kumpulan dari berbagai aspek kepribadian yang melambangkan kepribadian seseorang. Karakter merupakan ciri-ciri tertentu yang sudah menyatu pada diri seseorang yang ditampilkan dalam bentuk perilaku. Character education sebagai pendidikan ahklak. Sifat-sifat yang ada pada diri seseorang itu, terdapat sifat yang menonjol dan dominan, yang kemudian menjadi karakteristik seseorang atau sekelompok orang. sifat-sifat yang dimiliki manusia sangat ditentukan pendidikan yang mempengaruhinya. Pendidikan dapat mengembangkan potensi baik dan dapat menekan potensi buruk manusia.

Karakter merupakan kualitas moral dan mental yang pembentukannya dipengaruhi oleh factor bawaan (fitrah atau nature) dan lingkungan (sosialisasi aau lingkungan, nurture). Potensi karakter yang baik dimiliki seorang sebelum dilahirkan harus terus-menerus dikembangkan melalui sosialisasi dan pendidikan. Memahami aturan social dalam kehidupan dan menginternalisasikannya dalam diri anak didik dengan baik patut menjadi perhatian orang tua (keluarga), pendidik (sekolah), dan masyarakat. Kebiasaan membuang sampah pada tempatnya, antre, mematuhi aturan lalu lintas, mandiri, jujur, toleran, disiplin, tepat janji, dan sejenisnya, merupakan pemahaman yang baik anak didik terhadap aturan social sebagai hasil dari perkembangan kualitas moral dan mental seorang anak didik yang disebut karakter (Jalaluddin, 2017: 2014).

\section{Proses pembentukan Karakter}

Kebiasaan baik atau buruk pada diri seseorang anak didik dan generasi muda yang mengindikasi kualitas karakter dipengaruhi factor nuture dan nurture. Proses sosialisasi atau pendidikan dalam proses pembentukan karakter anak didik terletak pada peranan orang tua (keluarga), institusi pendidikan, masyarakat dan pemerintah (Jalaluddin, 2017: 215-228).

Proses pembentukan dan menanamkan nilai-nilai kebajikan (morak, karakter, ahklak) pada anak didik sangat tergantung pada jenis pola asuh yang diterapkan keluarga/orang tua pada anaknya. 
Pola asuh didefinikan sebagai pola interaksi antara anak dengan orang tua yang meliputi pemenuhan kebutuhan fisik (makan, minum dan lain-lain) dan kebutuhan psikologi (seperti rasa aman, kasih sayang dan lainlain), sertra sosialisasi norma-norma yang berlaku di masyarakatagar anak dapat hidup selaras dengan lingkungannya. Pola asuh juga meliputi pola interaksi antara orang tua dengan anak dalam rangka pendidikan karakter. Pola asuh ada tyiga jenis, meliputi pola asuh democratic, authoritative dan permissive. Pola asuh permissive yang cenderung memberikan kebebasan kepada anak untuk berbuat apa saja sangat tidak kondusif bagi pembentukan karakter anak. Bagaimanapun anak tetap memerlukan arahan dari orang tua untuk mengenal mana yang baik dan mana yang salah. Dengan memberikan kebebasan yang berlebihan, apalagiterkesan membiarkan, akan membuat anak bingung dan berpotensi salah arah. Pola asuh demokratis, tampaknya lebih kondusif dalam pendidikan karakter anak. Orang tua yang demokratis lebih mendukung perkembangan anak terutama dalam kemandirian dan tanggung jawabnya. Orang tua yang otoriter merugikan, karena anak tidak mandiri, kurang tanggung jawab serta agresif, sedangkan orang tua yang permisif mengakibatkan anak kurang mampu dalam menyesuaikan diri di masyarakat.

Keluarga mempunya peran yang terdepan dan strategis dalam pembentukan watak dasar atau karakter anak. Oleh karena itu keluargamerupakan lembaga pendidikan dasar atau pertama dan utama. Antara peran keluarga/orang tua dan pengembangan karakter pribadi anak didik tidak dapat dipisahkan. Jika anak tumbuh dalam keluarga yang lebih focus terhadap perkembangan anak, akan menumbuhkan peribadi anak yang berkarakter yang berdampak positif terhadap kemajuan bangsa ini.

Institusi pendidikan, sejak play group sampai perguruan tinggi, merupakan suatu institusi pendidikan yang bersifat artifisial. Keberadaannya dilaksanakan karena kebutuhan, sebagai petunjuk peran pendidikan keluarga. Institusi pendidikan diharapkan dapat mengambil alih peran dan tanggung jawab keluarga dalam meneruskan watak anak didik. Focus pembentukan watak dan karakter di institusi pendidikan formal adalah menanamkan nilai-nilai untuk menyadarkan kesucian sebagai factor bawaan manusia. Nilai-nilai tersebut mengacu kepada kebenaran, kebaikan dan keindahan. Pada hakikatnya manusia senang akan yayang benar dan benci yang salah, senang yang baik dan benci yang buruk, serta senang yang indah dan benci yang jelek.

Dalam tataran aplikasinya, institusi pendidikan dasar memiliki peran penting dalam pembentukan system nilai melalui tata tertibb yang ketat. Penekatan terhadap ketertiban merupakan siasat supaya anak didik terbiasa terhadap sikap yang diharapkan. Tujuan finalnya adalah terbentuknya sifat disiplin, jujur, tanggung jawab, adil dan cinta kebenaran, yang tertanam dalam diri anak didik. Pendidikan formal pada level menengah, berada pada usia remaja. Periode perkembangan ini, ditandai dengan karakteristik tertentu, yang meluputi: perkembangan berfikir rational, etika, estetika, social, minat dan agama. Peran institusi pendidikan pada level ini, adalah memberi bimbingan agar potensi mental spiritual anak didik dapat berkembang dengan optimal. Pada level perguruan tinggi, mahasiswa berada pada tahap adolescence. Pada tahap pekembngan ini, mahasiswa akan mengalami masa krisis yang ditandai gejolak bathin, dan kelihatan ragu dalam menentukan sikap. Hal ini merupakan proses natural dalam perjalanan menuju ke pembentukan kepribadian yang mantap.

Seorang guru memiliki pengaruh sebagai paramount. Pendidik sebagai exemplar moral dan moral guide, dimana seorang anak belajar dengan meniru apa yang dilakukan guruketimbang apa yang dikatakan guru. Guru tidak hanya transfer ilmu pengetahuan, tetapi jug abertanggung jawab terhadap perkembangan personalitas, karakter, kapasitas mengambil keputusan dan perilaku yang baik. Pendidik memiliki pengaruh yang maksimal dalam pengembangan moral anak didik. Pada 
periode infansi, anak-anak ingin diasumsikan dan menyenangi mainan dan aktivitas praktik. Pada periode anak-anak, mereka lebih tertarik pada penampilan luar, sebagai remaja mereka mengembangakan pesatnya pertumbuhan, mereka mungkin memperoleh dominasi pikiran-pikiran oleh imajinasi-imajinasi seksual. Sebagi orang dewasa muda mereka menunjukkan untuk posisi tanggung jawab, keuasaan dan kepemimpinan. Tetapi sebelum umur 40 tahun, mereka menjadi lebih spiritual, lebih menyadari terhadap dunia akan datang, dan lebih antusia untuk mengembangkan pengetahuan terhadap Tuhan. Pendidikan moral disiplin dan control moral untuk kehidupan anak-anak dalam suatu cara atau jalan pengembangannya. Kompetisi kekuatan yang sedang tumbuh, antara kekuatan birokrasi dan formalitas pengetahuan yang sedang tumbuh dengan kekuatan didasarkan pada kreatifitas dan jaringan. Yang cepat mengalahkan yang lambat, dan yang besar mengalahkan yang kecil. Dunia pendidikan umumnya kurang menyadari keadaan ini, dibandingkan dunia industry, sehingga banyak sarjana yang menganggur.

Ketiga peranan pemerintah.

Permasalahan pendidikan, sering kali mengartikannya secara sempit, dann belum mengangkatnya ke dalam permasalahan yang lebih luas. Tanpa memerhatikan kondisi makro, seperti kekuatan ekonomi, politik dan birokrasi yang berkembang, masalah besar yang sifatnya mendasar dalam proses pendidikan akan sulit tersentuh. Bertalian dengan tantangan zaman pada masyarakat modern, sumber ddaya manusia sering diabaikan, yang seharusnya dipersiapkan. SDM unggul terbukti lebih menentukan kemajuan suatu bangsa. Sumber daya manusia Indonesia bertalian erat dengan peranan sector pendidikan. Dalam UU no 20/2003 pasal 3 tentang system pendidikan nasional, dinyatakan:

Pendidikan Nasional berfungsi mengembangkan kemampuan dan membentuk watak serta peradaban bangsa yang bermartabat dalam rangka mencerdaskan kehidupan bangsa, bertujuan untuk berkembangnya perserta didik agar menjadi manusia yang beriman dan bertakwa kepada Tuhan Yang Maha Esa, berahklak mulia, berilmu, cakap, kratif, mandiri, dan manjadi warga Negara yang demokratis serta bertanggung jawab.

Antara pendidikan dan peranan pemerintah tidak dapat dipisahkan satu sama lain. Kemajuan suatu bangsa sangat ditentukan pembangaunan sector kesehatan, dan kesejahteraana ekonomi. Indeks Pembangunan Manusia (IPM) adalah alat untuk mengukur kualitas sumber daya manusia suatu Negara, yang diukur yakni pendidikan, kesehatan dan kesejahteraan ekonomi. Alat tersebut menjadi dasar klasifikasi sebuah Negara menjadi Negara maju, Negara berkembang dan Negara terbelakang.

Pertumbuhan dan pembinaan karakter genertasi muda yang paling strategis, terletak pada kebijakan Negara/pemerintah. IPM meningkat idealnya akan memperbaiki proses pembinaan karakter generasi muda suatu bangsa. Sama halnya optimalisasi, keseriusan dan konsistensi peran pemerintah dalam melaksanakan program kebijakan pembangunan dengan merujuk dimensi IPM (pendidikan, kesehatan dan kesejahteraan ekonomi), akan sangat mungkin meningkatkan IPM dan kualitas pembangunan karakter generasi muda Indonesia yang lebih baik. Jika dimensidimensi IPM meningkat, proses pendidikan dan pembinaan karakter generasi muda diharapkan akan lebih baik, dapat mereduksi beragam permasalahan social berbangsa dan menguatkan national character building.

Maju mundurnya suatu bangsa, lebh ditentukan kualitas karakter individu dalam suatu bangsa. Institusi pendidikan memiliki peranan strategis dalam menciptakan iklim akademik yag diharapkan mampu membentuk suatu karakter anak didik sebagai generasi masa depan yang dapat beradaptasi dan mengaplikasikan ilmu dan pengalaman dalam masyarakat yang senantiasa dinamis. Karena institusi pendidikan memiliki peran 
signnifikan dalam menentukan dan menciptakan cita-cita dan masa depan bangsa, berbagai optimalisasi kegiatan akademikdan program prekuliahan tidak hanya dengedepankan kognitif, afektif, tetapi juga psikomotorik. Aktifitas pembelajaran di sekolah dan aktifitas perkuiahan di perguruan tinggi diharapkan berupaya menciptakan anak didik atau mahasiswa tidak hanya unggul dalam bidang sains-teknologi tetapi juga unggul dalam sains-agama (nilai-nilai karakter).

Maju mundurnya masa depan bangsa, sangat ditentukan kualitas sumber daya manusia yang cerdas, berkarakter, berahklak, sesuai dengan falsafah dan tujuan pendidikan nasional. Cita-cita pendidikan nasional adalah menciptakan manusia Indonesia yang berkeperibadian, cerdas, pintar tetapi juga berahklak dan berkarakter. Bangsa ini akan menjadi maju dan berkepribadian jika dimensi sains-teknologi dan sains-agama menjadi perhatian dan komitmen terdepan dalam pelaksanaan pendidikan nasional ataupun pembangaunan bangsa. Tujuan filosofis pendidikan nasional pada prinsipnya relevan dengan tujuan pembangunan dan tujuan pendidikan nasional, yakni berupaya dalam pembinaan karakter anak didik den generasi muda yang memiliki tugas dan amanah untuk menjaga dan melestarikan identitas bangsa dan penentu kemajuan peradaban bangsa kemudian hari.

\section{Penutup}

Terciptanya kurikulum pendidikan tertentu untuk pendidikan tertentu. Tercipta kurikulum pendidikan kurikulum pendidikan agama, kurikulum pendidikan vokasi untuk menyelenggarakan pendidikan keterampilan. Mengapa? Karena secara ontologis telah diketahui dari awal bahwa pemikiran filsafat itu tujuan pendidikannya berdasarkan "Yang Ada" untuk agama, atau "Yang Ada" untuk vokasi.

Landasan epistemologis memberikan dasar filsafat bagi teori dan praktik pendidikan dalam hal cara memperoleh pengetahuan. Pendidikan itu sangat erat kaitannya dengan ilmu pengetahuan, maka pandangan mengenai sumber dan jenis pengetahuan akan sangat berpengaruh terhadap kurikulum dan model atau metode pembelajaran (pengajaran).

Dalam ranah pendidikan, landasan aksiologis memberikan dasar-dasar filsafat dalam hal nilai dan moral yang melandasi teori pendidikan dan menjadi acuan dalam praktik pendidikan. Karena, pendidikan tanpa nilai dan moral yang positif, pendidikan justru dapat memberikan hal yang negatif. Pendidikan haruslah diimbangi dengan adalah adanya pemberi, penerima, tujuan, dan cara yang baik, dalam konteks yang positif.

Maju mundurnya masa depan bangsa, sangat ditentukan kualitas sumber daya manusia yang cerdas, berkarakter, berahklak, sesuai dengan falsafah dan tujuan pendidikan nasional. Cita-cita pendidikan nasional adalah menciptakan manusia Indonesia yang berkeperibadian, cerdas, pintar tetapi juga berahklak dan berkarakter.

\section{Daftar Pustaka}

Abidin, Zainal. 2009. Filsafat Manusia Mmemaahami Manusia melalui Filsafat. Bandung: PT Remaja Rosdakarya.

Bakhtiar, Amsal. 2007. Filsafat Ilmu. Jakarta: Raja Grafindo Persada.

Jalaluddin. 2017. Filsafat Pendidikan: Manusia, Filsafat dan Pendidikan. Depok: Rajawali Pers.

Pandit, Bansi. 2003. Pemikiran Hindu PokokPokok Pikiran Agama Hindu dan Filsafatnya. Surabaya: Paramita.

Sudarminta, J. 2017. Epistimologi Dasar pengantar Filsafat pengetahuan. Yogyakarta: PT Kanisius.

Undang-Undang Republik Indonesia No 20 Tahun 2003 tentang Sistem Pendidikan Nasional.

www.beritaindonesia.co.id, diakses: $14 / 11 / 2020$

https://serupa.id/filsafat-pendidikanpengertian-sistematika-tujuan-aliran/, diakses: 14/11/2020 